УДК 902/904 (902.01)

DOI: https://doi.org/10.33782/eminak2019.1(25).214

\title{
ЗОВНІШНІЙ ШТАМПОВАНИЙ ОРНАМЕНТ НА АТТИЧНІЙ ЧОРНОЛАКОВІЙ КЕРАМІЦІ 3 ОЛЬВІЇ
}

\author{
Ірина Чечуліна \\ Інститут археології НАН України (Київ, Україна) \\ e-mail: irynachechulina@gmail.com \\ ORCID: https://orcid.org/0000-0003-3783-6277
}

Штампований і врізний орнамент належить до найбільш поширених методів орнаментації чорнолакової кераміки. Ці методи орнаментації використовували з середини V cm. до н.е. до елліністичного періоду, техніка поширилася від Афін до Італії. Штампами могли прикрашати посуд як всередині, так і ззовні. Зовнішні штампи зустрічаються набагато рідше, ніж внутрішні.

Аналіз чорнолакового посуду з Ольвії показав, що лише декілька відсотків штампованого посуду мають штампи по зовнішній стороні. Проте матеріал репрезентує всі зміни у морфології й орнаментації, що характерні класичних екземплярів. Це ще раз доводить тісні та системні торгівельні зв'язки Ольвійського полісу з Афінами та їі округою у класичний період.

Ключові слова: Північне Причорномор'я, Ольвія, аттична чорнолакова кераміка, технологія виробництва, чорний лак, штампований орнамент

Аттична чорнолакова кераміка займає помітне місце серед численних категорій археологічного матеріалу в Ольвії. Даний посуд виготовляли в Аттиці і разом 3 іншими товарами масово експортували до Північного Причорномор'я. Завдяки досить помітній зміні морфологічних особливостей і схем орнаментування посуду на тлі ретельно стратифікованих будівельних комплексів Афін, його можна доволі детально продатувати. Знахідки аттичного столового та парадного посуду в північнопричорноморських містах є масовими і тому - надзвичайно важливими 3 точки зору його інформативності для детальних хронологічних розробок.

Штампований і врізний орнамент належить до найбільш поширених методів орнаментації чорнолакової кераміки. Його досить широко застосовували для орнаментації посудин відкритого типу - насамперед на внутрішній, придонній частині посудини, проте зустрічаються штампи і на зовнішній частині посудин. Розквіт цього стилю орнаментації приходить на 440-430 рр. до н.е., саме для цього часу всі орнаменти мають дивовижно чіткі та геометрично правильні формиํㅡ. Протягом V cт. до н.е. збільшується загальна кількість типів посуду з прокресленим і штампованим орнаментом, зокрема й набір орнаментації. Це пов’язано зі зростанням популярності цього виду посуду та зі зростанням його імпорту, зокрема i до Північнопричорноморського регіону².

Сам метод врізного орнаменту першопочатково використовували для прикра-

\footnotetext{
${ }^{1}$ Sparkes B.A., Talcott L. Black and Plain Pottery of the 6th, 5th and 4th Centuries B.C. (The Athenian Agora, Vol. XII). Princeton: American School of Classical Studies at Athens, 1970. P. 22.

2 Егорова T.E. Чернолаковая керамика V-IV вв. до н.э. с прочерченным и штампованным орнаментом из раскопок Пантикапея // С Митридата дует ветер. Боспор и Причерноморье в античности. К 70-летию В.П. Толстикова. Москва, 2015. С. 64.
} 
шення простого гончарного посуду, пізніше - при розписах червонофігурної та чорнофігурної кераміки. Прикрашати чорнолаковий посуд штампованим і врізним орнаментом почали, як вважається, в Афінах у середині V ст. до н.е., саме з цього полісу ця техніка поширилася на гончарну продукцію інших міст грецької ойкумени ${ }^{3}$. Гончарі, які вперше використовували таку техніку для прикрашення посуду, ймовірно, адаптували ідею прикрашення металевого посуду. А згодом вже майстри по металу копіювали основні мотиви штампів для декору простого посуду.

Певно, що деякі мотиви могли бути запозичені з монументального мистецтва, передовсім архітектури, перш за все, із зовнішніх прикрас будівель. Крім того, сама техніка орнаментації могла бути запозичена і в Коринфі. В Афінах штампами прикрашали великі піфоси протягом VI ст. до н.е., ця традиція пізніше була тут втрачена. Проте у Коринфі вона використовувалась для орнаментації різнотипних ваз, хоч і не чорнолакових, ще у V ст. до н.е. Таким чином, стару технологію в Аттиці використали по новому. При цьому афінські майстри не копіювали коринфські мотиви, а створювали свої. Отже, першопочатково, вирізний орнамент використовували лише як додаток до розписів.

Серед дослідників існує і така думка, що орнаментація бере початок тоді, коли кожна посудина була унікальною і сам орнамент вирізався вручну майстром ${ }^{4}$. Таким орнаментом зазвичай прикрашали посуд для пиття та посудини для зберігання олій. Як виняток - прикрашали гідрії, ойнохої, але прийнято вважати, що й ці форми могли використовуватись в якості парфумерних посудин, особливо ті, що мали невеликі розміри. Серед інших форм такий орнамент зустрічається вкрай рідко5.

Загалом, технологію виготовлення чорнолакового посуду можемо окреслити наступним чином: підготовка матеріалів (глини та покриття), формовка посуду, нанесення орнаментів, застигання форми, трьохрівневий обпал, охолодження посуду.

Сама ж техніка досить проста - використовували небагатий набір інструментів різець, лінійку, циркуль і сам штамп з нанесеним на ньому рельєфним орнаментом 6 . Орнамент наносився спеціальними штампами - ці знаряддя, ймовірно, було виготовлено з глини, до обпалу на ньому вирізали потрібний орнамент таким чином, що при відтисканні отримати потрібний декор. На посуд орнамент наносився відбитками не одномоментно, а поступово натискаючи, відповідно до повороту посудини по колу, після цього посуд покривали чорним «лаком» та обпалювали7.

Цікаво, що один окремий штамп може дати широкий спектр різних відбитків. Всі відмінності пояснюються різною формою самого штампу та шляхом, яким це було зроблено. Ймовірно, що штамп був трохи опуклим, не пласким. Майстер робив відтиск не прямим натиском штампа прямо вниз у глину, а під кутом, верх штампа повертався круговими рухами таким чином, щоб центральна точка залишалась непорушною ${ }^{8}$.

\footnotetext{
3 Sparkes B.A., Talcott L. Op. cit. P. 22-23.

4 Talcott L. Attic Black-Glazed Stamped Ware and Other Pottery from a Fifth Century Well // Hesperia (Princeton). 1935. Vol. 4, № 3: The American Excavations in the Athenian Agora: Seventh Report. P. 489. 5 Gill D. Stamped palmettes and an attic black-glazed oinochoe // Oxford Journal of Archaeology. 1990. Vol. 9, issue 3. P. 369.

${ }^{6}$ Sparkes B.A., Talcott L. Op. cit. P. 24-25.

7 Егорова T.Е. Чернолаковая керамика IV-II вв.до н.е. с памятников Северо-Западного Крыма. Москва: МГУ им. М.В. Ломоносова. 2009. С. 20.

8 Corbett P. Palmette stamp from an Attic Black Glazed Workshop // Hesperia (Princeton). 1955. Vol. 24. P. 172.
} 
Майстер, який зробив штамп неякісно, міг зробити його повторно на цьому ж місці. Саме від рухів майстра залежала якість відбитку пальметки. Наприклад, при нерівномірному надавлюванні замість звичайних дев'яти пелюсток - лише вісім. Пальметки можуть бути як опуклими, так і увігнутими та пласкими. Зустрічаються пальметки, в яких є всі пелюстки, всі волюти цілі. Проте багато таких, де волюти обрізані, деякі пелюстки ширші за інші. Отже, якість виконання орнаментів напряму залежала від охайності майстра9 ${ }^{9}$ При сильному надавлюванні штампом на поверхню посудини пальметки виходять більш рельєфними й об'ємними. Вважається, що це означало певне здешевлення виробництва, його масовість. Чим більш відточене та тонке зображення - тим коротшими рухами наносився орнамент ${ }^{10}$.

Майстер планував свій малюнок за допомогою легких концентричних жолобків і точок, щоб позначити місце, де буде зображено той чи інший мотив. На цьому етапі виготовлення посуду глина, зазвичай, ще не дуже міцна, тож часто посудину ще могли підправити, так само як і штамп могли рихтувати. Більш механічний метод нанесення штампів у IV ст. до н.е. репрезентує винахід методу «рулетки», що з'явився у $390-380$ рр. до н.е. ${ }^{11}$

$€$ два основні типи такого орнаменту. Більш ранній тип нагадує штришки від шиття, що йдуть по колу, другий тип представляє з себе паралельно нанесені штришки однакового розміру, що закручуються спіраллю. Цей орнамент наносився наступним чином: тонка смужка з металу з одного боку ставилась на посудину в тому місці, де майстер хотів нанести орнамент; при обертанні колеса смужка підстрибувала таким чином, що утворювався переривчатий орнамент. Ймовірно, що такий вид орнаменту було винайдено випадково. За необхідності пришвидшити процес нанесення орнаменту, насічки стали гарною альтернативою для ов.

Спершу насічки комбінувались 3 іншими елементами, потім вони повністю замінюють ови, використовуються у якості межі між рядами пальметок. У другій чверті V cт. до н.е., коли подібні насічки з'являються вперше на аттичному посуді, існувала стереотипна схема орнаменту - спіралі з насічок - ов, що відокремлюють пальметки ${ }^{12}$.

Загалом, штампи завжди у різних варіаціях складаються з пальметок, кілець, геометричних фігур, ліній і точок. Усі типи штампованих орнаментів умовно можна розділити на такі, що включають елементи рослинного походження та геометричні: ови, пальметки, квітки лотосу, листя плюща, оливкова гілка, меандр, листя, трикутники ${ }^{13}$.

Усі типи штампованих орнаментів умовно можна розділити на такі, що включають елементи рослинного походження та геометричні: ови, пальметки, квітки лотосу, листя плюща, оливкова гілка, меандр, листя, трикутники ${ }^{14}$. Ови з'явилися на посуді від кінця V ст. до н.е. Як правило, вони поєднувалися з іншими декоративними елементами. Однак найбільш популярним мотивом, який почав використовуватися разом з овами, були пальметки. Їх кількість у центрі штампу могла варіюватися від

\footnotetext{
9 Ibid. P. 174.

10 Talcott L. Op. cit. P. 487.

${ }^{11}$ Sparkes B.A., Talcott L. Op. cit. P. 23.

12 Ibid. P. 30.

13 Чечуліна I.О. Штампований орнамент на аттичній чорнолаковій кераміці з Ольвії // Археологія. 2016. № 2. C. 29-38.

14 Sparkes B.A., Talcott L. Op. cit. P. 25-26.
} 
трьох до дванадцяти, часто вони були оточені колом із ов або колами з насічок, нерідко поєднані радіальними лініями. Пальметки мали різну форму - з закругленими чи гострими кінцями, з чітко відокремленими валютами або майже злитими 3 пелюстками ${ }^{15}$. Часто пальметки оточені рядом насічок, вони могли поєднуватися врізаними радіальними лініями ${ }^{16}$.

У V - першій половині IV ст. до н.е. переважали складні схеми орнаментації, що включали у себе комбінації з пальметок, дуг, ов та окружності різного розміру. Наприкінці V ст. до н.е. з'явилися пальметки й окружності вже без ов. 3 середини IV ст. до н.е. ови зникають, їх змінює різна кількість рядів насічок різного розміру, з останньої чверті IV ст. до н.е. - навколо пальметок. Орнамент з пальметок і насічок був найбільш популярний для посуду кінця IV - першої половини III ст. до н.е., що й робить його основною датуючою ознакою посуду цього часу. 3 другої чверті III ст. до н.е. штамповані орнаменти поступово зникають із широкого вжитку17.

Квітки лотосу - рідкісний орнамент, характерний лише для V cт. до н.е. В елліністичний період така техніка майже відсутня, головним чином вони прикрашаються миски та тарілки кінця IV - першої половини III ст. до н.е. - як продовження розвитку класичних форм. Листя плюща зустрічаються значно частіше зображень лотоса. Можуть складатись як з цілої гілки, так і з окремих листочків. Ще більш рідкісний елемент - оливкова гілка, як правило, нею прикрашали чаші одного типу «болсал» (bolsal). Орнамент складався з концентричного кола та оливкової гілки навколо неї. Меандром прикрашали закриті посудини, амфорискі та лекифи, значно рідше - внутрішню частину киліків. Переважно використовували підквадратний варіант меандру. Ще одним рідкісним елементом $є$ зображення стилізованого листя - переважно, у центрі композиції. Рівносторонніми трикутниками, в основному, прикрашали винятково канфари, при цьому самі трикутники всередині заштриховувались паралельними лініями. Унікальним елементом $є$ так звані діаманти - звичайно, мається на увазі зображення якоїсь підвіски ${ }^{18}$.

Серед знахідок з Ольвії19 збереглася досить незначна кількість фрагментів посудин із зовнішнім орнаментом, які за аналогіями можна впевнено віднести до класичного періоду. 3 численного матеріалу, лише декілька відсотків складає посуд, прикрашений зовнішніми штампами, що підкреслює особливість і важливість таких матеріалів. Ті, що піддаються атрибуції та датуванню - відносяться до проміжку часу з кінця другої чверті V - до кінця IV ст. до н.е., всі екземпляри є продукцією аттичних майстерень.

Аналіз імпортного матеріалу зі штампованим орнаментом з Ольвії, який датуються й по формі, доводить думку, що найбільш раннім елементом $\epsilon$ ови у різноманітних комбінаціях. 3 IV ст. до н.е. характерні орнаменти з різних пальметок, які можуть бути з'єднані між собою радіальними лініями, або ж бути окремо одна від одної. Подібні елементи можуть комбінуватись з колами по центру, рядами 3

15 Talcott L. Op. cit. P. 487.

16 Егорова T.Е. Чернолаковая керамика IV-II вв. до н.е. с памятников Северо-Западного Крыма... C. 20.

17 Егорова Т.Е. Предварительный анализ комплекса чернолаковой керамики VI-II вв. до н.э. из раскопок Пантикапея 1945-1992 гг. // Древности Боспора. 2014. Т. 18. С. 176.

18 Sparkes B.A., Talcott L. Op. cit. P. 26.

19 Колекція № 29, зберігається у Наукових фондах IА НАНУ. Колекція 1950-1970-х рр. зберігається у фондах заповідника НIA3 «Ольвія». Щиро завдячую Т. Шевченко за сприяння у науковій обробці керамічної колекції Ольвійської колекції. 
насічок. Прикрашати ж посуд по зовнішній стороні почали з останньої чверті V ст. до н.е. і цікаво, що малюнки не дублюються на сто відсотків 20.

Отже, для закритих типів посуду характерні наступні орнаменти. На лекифах і гутусах з першої чверті V ст. до початку IV ст. до н.е. характерне різноманіття елементів: листя плюща, симетричні ряди маленьких і великих однакових об'ємних куль, пальметки різних розмірів, язички, ови біля шийок, унікальним для цього типу посуду є зображення «діамантів» - у формі маленьких ромбів, або підвісок. Меандр $є$ характерним елементом орнаментації лекифів та амфорисків.

Слід зазначити, що звісно не всі форми лекифів кінця V ст. до н.е. прикрашали орнаментами, проте це було доволі поширеним явищем. В основному, прикрашали низькі типи лекифів («Squat») з вертикальними ребрами та цікавий, проте доволі рідкий тип «Galaxidi»- 3 видовженим тілом, високою ніжкою та шиєю. Останній прикрашали дуже щільним орнаментом - довгими «язичками», заповненими зсередини маленькими кружками. Подібні орнаменти зустрічаємо серед матеріалів 3 Ольвї - непоодинокі знахідки штампів, у вигляді з’єднаних між собою пальметок, волютами доверху; коло з ов 21.

Чорнолакові амфориски зі штампами виникають як адаптація великих кувшинів для вина (430 р. до н.е. - початок IV ст. до н.е.). Такі амфориски завжди мають стандартну форму, проте сам орнамент різниться деталями. Найбільш поширений наступний орнамент - стрічка меандру посередині ділить тіло на дві частини; два вільних поля можуть бути орнаментовані по різному; іноді у дзеркальному порядку або просто грубо схожі між собою. Іноді прикрашали орнаментом у вигляді великих веретеноподібних пальметок, проте їх не могло бути багато. Для більшості пізніших форм характерна наступна орнаментація: замість центрального меандру йде три жолобки, плечки прикрашені колами з ов (цей орнамент копіює червонофігурний декор на розписних амфорах). Зовсім рідким орнаментом, як вже зазначалося, $є$ намисто з «діамантів» і пальметки по колуг2.

Ще однією варіацією є наступні комбінації - посередині тулова підквадратний меандр, обмежований лініями, ділить поверхню на два поля; зверху - вишукані квітки лотосу, з листям; знизу - лотоси, листям догори. Таким чином утворювався ніби дзеркальний орнамент. Іноді подібні комбінації доповнювалися об’ємними кружечками над меандром²3; в інших випадках під горлом наносилося коло з ов, далі - два ряди з'єднаних між собою пальметок, один ряд - волютами догори, між ними ряд з кружечків ${ }^{24}$.

Серед ольвійського матеріалу посуд закритого типу зі штампованим орнаментом, з оброблених колекцій, представлений незначною кількістю фрагментів амфорисків і лекифів, які всі представлені посудом 450-420 рр. до н.е. (рис. 1).

Увагу привертає фрагмент амфориску 420-х рр. до н.е., на якому поєднані популярні елементи - підквадратний меандр, обмежений з обох боків прокресленими

\footnotetext{
20 Егорова T.Е. Чернолаковая керамика V-IV вв. до н.э.... С. 64.

21 Русяева А.С., Назарчук В.И. Аттическая керамика. Древнейший теменос Ольвии Понтийской // МАИЭГ. Supplementum. Вып. 2. Симферополь, 2006. С. 176, 462.

22 Sparkes B.A., Talcott L. Op. cit. P. 155.

${ }^{23}$ Braunova D., Cadic J., Dufkova M. Corpus Vasorum Antiquorum. République Tchèque, 4 (Pilsen, Musée de la Boheme de l'Ouest). Pilsen, Prague, 2000. P. 49.

24 Рогов Е.Я., Кашаев С.В., Форназир Й. Керамический комплекс из хозяйственных ям поселений Вышестеблиевская-11 на юге Таманского полуострова // Боспорские исследования. 2005. № 8. C. 214.
} 
лініями, під якими йдуть лінії з ов, знизу знаходиться досить чітко та детально окреслена пальметка з дванадцятьма пелюстками та чітко окресленою серцевиною ромбоподібної форми (рис. 1,1$)$. Зустрічаються амфориски ${ }^{25}$, тулово яких повністю заповнено штампом (рис. 1,7). У даному випадку під горлом йдуть ови; тулово розділене на три поля подвійними лініями - кожне поле заповнене пальметками, причому нижній ряд йде валютами доверху. Цікавим є й фрагмент лекифу цього ж часу, де зображена пальметка та два трикутники, що складаються з ліній, прокреслених ніби «ялинкою» (рис. 1,2). Інші фрагменти є класичними взірцями зовнішніх штампів - горизонтально прокреслена товста лінія, під якою нанесені пальметки на деякій відстані одна від одної, деінде без чітко вираженої серцевини (рис. 1,3$)$. Подібний орнамент має фрагмент, ймовірно, гутусу (рис. 1,4) - лінія та ряд з пальметок на одній відстані одна від одної. Слід зазначити, що майстер не придавав особливого значення повній одноманітності пальметок - в одному випадку бачимо пальметку з серцевиною, в іншому - без неї та навіть без волют. Різними варіаціями кола з ов прикрашено верхню частину, ймовірно, лекифу. Цікаво, що є ряд ов зовсім маленьких, з серединкою, навколо якого $є$ ряд з ов великих, майже неохайних; всі елементи відмежовані лініями (рис. 1, 5).

Щодо такої форми, як гутуси, то їх орнаментація не вирізнялася особливістю. Прикрашали частину зверху, навколо отвору для наливання рідини. Це могли бути сім або дев'ять пальметок²6, з'єднаних між собою, іноді по внутрішній частині додається коло $з$ ов$^{27}$.

Штампованими орнаментами прикрашали й чорнолакові ойнохої - з'єднаними між собою пальметками на плічках, або ж колами 3 ов на самому тулові 28 . Цей тип посуду прикрашали штампованим орнаментом з VI ст. до н.е.29.

Цікаво, що посуд відкритого типу теж нерідко прикрашався з3овні. Для чаш 450425 рр. до н.е. спостерігаємо наступні: поєднання зображень плюща та пальметок; зображення пальметок між рельєфними канелюрами, відокремлені лініями; вертикальні язички різних розмірів; зображення лотоса, з'єднані між собою лініями. Слід зазначити, що протягом п'ятдесяти років інтенсивного виробництва цього типу посуду, майстри випробували багато типів оздоблення кераміки. Оскільки майже завжди чаші мали ребристу поверхню (вертикальні канелюри), то є логічним, що багато місця для штампів не було. Використовували простір під ручками (високий тип), прикрашали поширеним для цього типу орнаментом - трикутники з ов чи пальметки. Інші орнаменти, що розміщувались під ручкою - подвійна пальметка перетинає листя плюща; зображення виконане настільки ретельно, що видні всі жилки на листі. Іноді використовували простір між ребрами (наприклад заповнювали пальметками). Нижню частину чаші могли прикрашати штампованими кружечками, рельєфними вертикальними пелюстками в два ряди, між якими йде коло з ов. Одиничні екземпляри прикрашали лотосом та пальметками ${ }^{30}$.

\footnotetext{
${ }^{25}$ Handberg S., Peterson J.H. Black-glossed pottery // The Lower City of Olbia (Sector NGS) in the $6^{\text {th }}$ Century BC to the $4^{\text {th }}$ Century A.D. Aarchus, 2010. P. 187-196.

${ }^{26}$ Kunze-Götte E., Tancke K., Vierneisel K. Die Nekropole von der Mitte des 6. bis zum Ende des 5. Jahrhunderts: die Beigaben, Kerameikos. Ergebnisse der Ausgrabungen VII.2, München 1999.

${ }^{27}$ Knige U. Kerameikos. Ergebnisse der Ausgrabungen. Band IX, Der Südhügel. Berlin, 1976. P. 153.

28 Gill D.W.J. Stamped palmettes and an attic black-glazed oinochoe // Oxford Journal of Archaeology. 1990. Vol. 9, issue 3. P. 369.

29 Talcott L. Op. cit. P. 489.

30 Sparkes B.A., Talcott L. Op. cit. P. 74.
} 

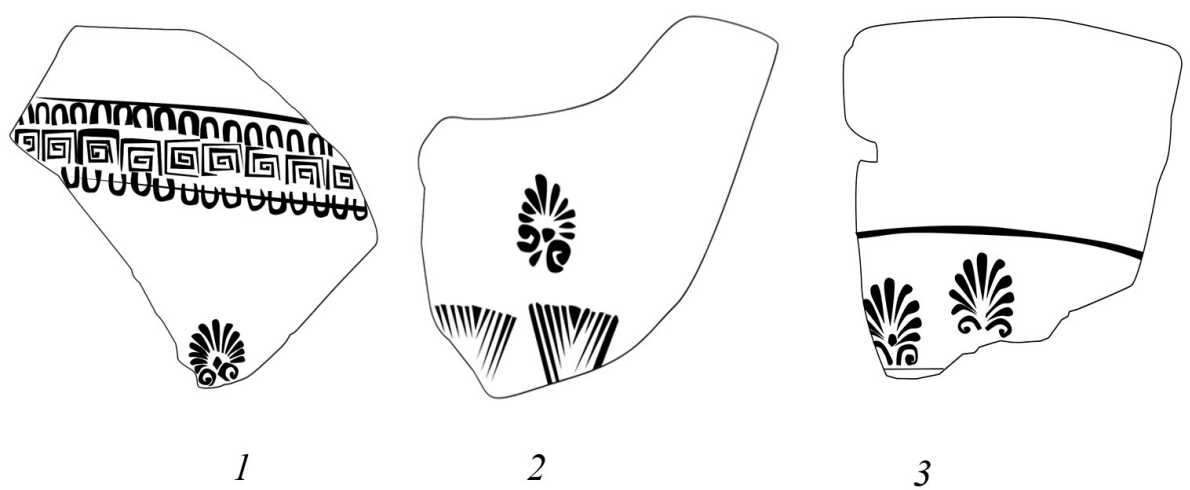

3
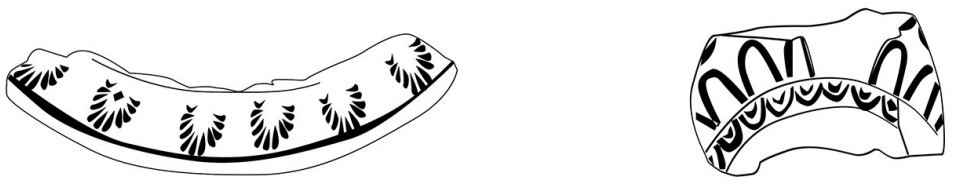

4
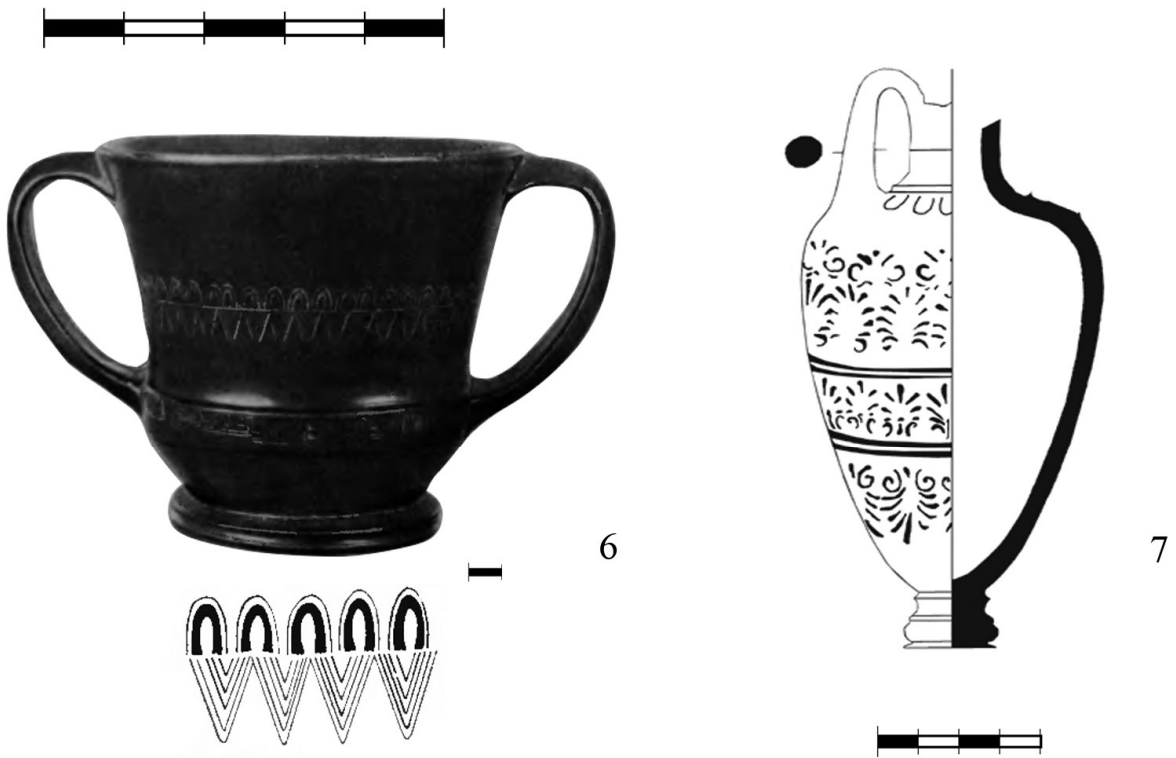

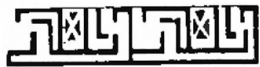

Puc. 1. Зовнішній штампований орнамент: 1 - 0-38-691, аналогія: Sparkes, Talcott 1970, cat. Nr. 639, 450425 р. до н.е. , 2 - 0-46-576, аналогія: Sparkes, Talcott 1970, cat. Nr. 635, 450-425 р. до н.е., 3 - 0-62-3375, аналогія: Sparkes, Talcott 1970, cat. Nr. 634, 450-425 р. до н.е., 4 - 0-52-3104 Sparkes, Talcott 1970, cat. Nr. 1197, 450-425 р. до н.е. , 5 - 0-52-175 Sparkes, Talcott 1970, cat. Nr. 1157, 420 р. до н.е., 6 - М-90153231, 450-425 р. до н.е., 7 - Da 60832, аналогія: Sparkes, Talcott 1970, cat. Nr. 1159, 430-420 pр. до н.е.

31 Гайдукевич В.Ф. Указ. раб. С. 165.

32 Handberg S., Peterson J.H. Black-glossed pottery // The Lower City of Olbia (Sector NGS) in the $6^{\text {th }}$ Century BC to the $4^{\text {th }}$ Century A.D. Aarchus, 2010. P. 187-196. 

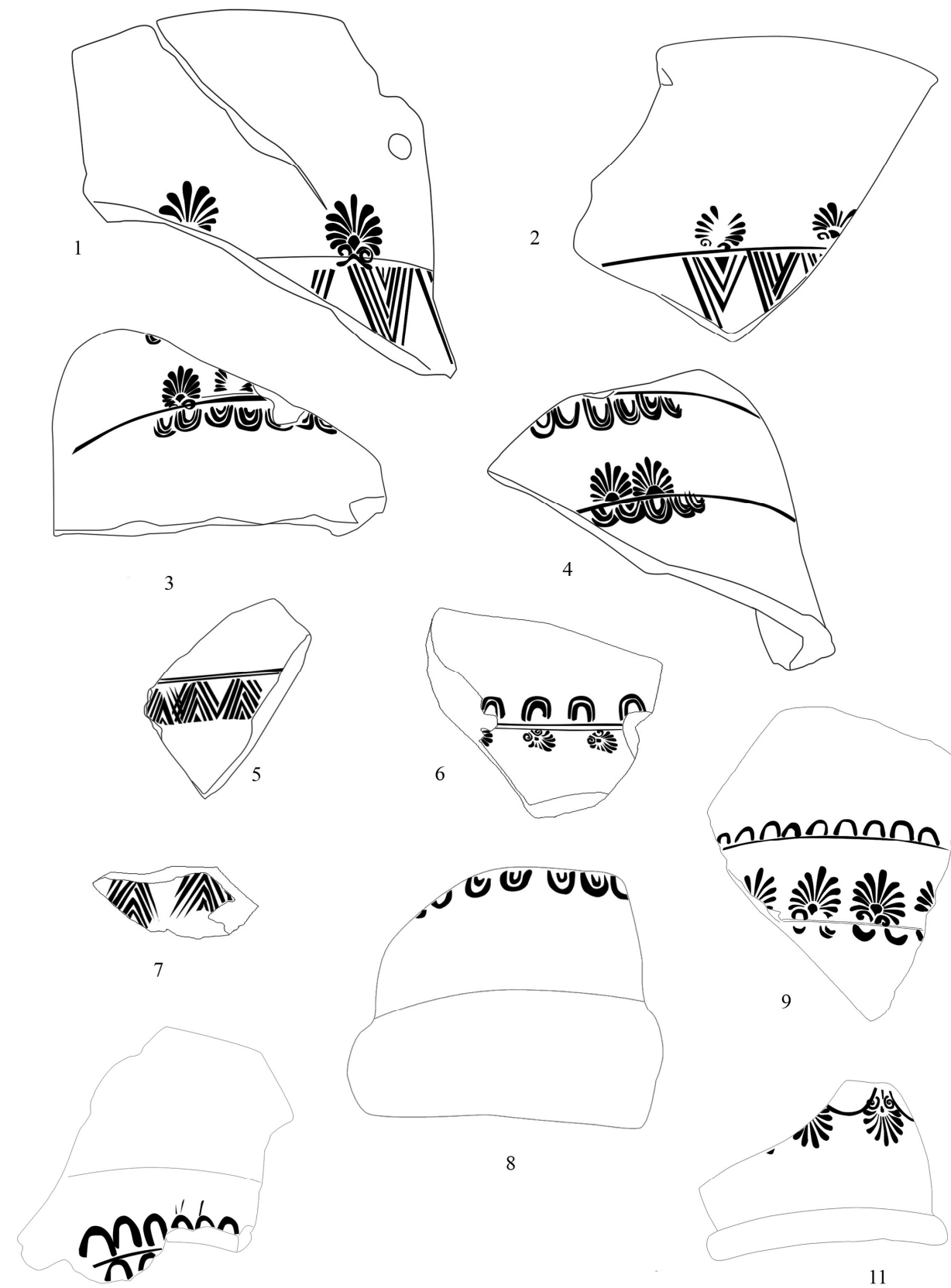

8
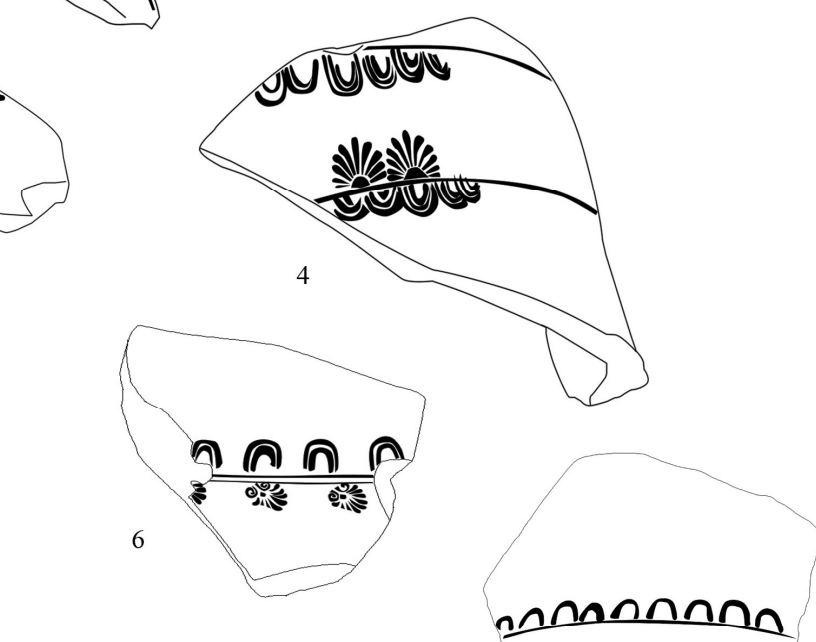

10

11

Puc. 2 Зовнішній штампований орнамент: 1 - 0-64-1546, аналогія: Sparkes, Talcott 1970, cat. Nr. 635, 450-425 р. до н.е., 2 - 0-64-119, аналогія: Sparkes, Talcott 1970, cat. Nr. 635, 450-425 p. до н.е., 3 - 064-598 аналогія: Sparkes, Talcott 1970, cat. Nr. 633, 450-425 р. до н.е., 4 - 0-64-598/1, аналогія: Sparkes, Talcott 1970, cat. Nr. 633, 450-425 р. до н.е., 5 - 0-61-89, аналогія: Sparkes, Talcott 1970, cat. Nr. 635, 450-425 р. до н.е., 6 - 0-2018-Некр-4/549 аналогія: Sparkes, Talcott 1970, cat. Nr. 633, 450425 р. до н.е., 7 - 0-2018-Некр-54933 аналогія: Sparkes, Talcott 1970, cat. Nr. 637, 420 pp. до н.е., 8 - 069-1969, 9 - 0-49-1815 аналогія: Sparkes, Talcott 1970, cat. Nr. 633, 450-425 р. до н.е., 10 - 0-63-1321, аналогія: Sparkes, Talcott 1970, cat. Nr. 633, 450-425 р. до н.е., 11 - 0-63-?.

33 Буйских А.В., Форнасье Й., Кузьмищев А.Г. Указ. раб. С. 52. 
Для низьких канфарів, їх ще називають кубкоподібними («sessile kantharos») 450420 рр. до н.е. характерні поєднання пальметок, ов, ліній; також зображують геометричний меандр, незавершені концентричні кола, рівносторонні трикутники, заповнені лініями ${ }^{34}$.

Не поодинокими серед ольвійського матеріалу є знахідки фрагментів канфарів класичного типу (рис. 2) (тип Б на піддоні з низькими ручками), що датуються у межах 450-425 рр. до н.е.; для них характерні наступні орнаментації: ряд пальметок, що йдуть по колу, лінія та ряд трикутників, виконаних лініями, що розташовані «ялинкою» (рис. 2, 1,2); два кола з ов, між ними ряд з пальметок, ніби підкреслений лінією (рис. 2, 3, 4); цікавим $\epsilon$ те, як на останньому фрагменті зображені пальметки, що мають не зовсім класичну форму, пелюстки розходяться від серцевини, ніби сонячні промені. Подібні орнаменти зустрічаються доволі часто, всі з класичними пальметками, по дев'ять і дванадцять пелюсток, виокремленою серцевиною та волютами (рис. 2, 9, 11).

Оскільки матеріал часто дуже фрагментований, важко виділити тип посуду, проте саме окремі частини орнаменту допомагають визначитись з типом (рис. 2, 5). На цьому фрагменті залишилась лише орнаментація у вигляді заштрихованих трикутників «ялинкою». Подібних фрагментів було виявлено декілька (рис. 2, 7). За аналогіями вони датуються у межах 450-430 pр. до н.е. Відомі цілі знахідки таких $\phi$ орм$^{35}$, тож маємо змогу побачити, як виглядали подібні орнаменти на цілих посудинах (рис. 1, 6). Комбінація вже знайомих елементів - два жолобки, ряд 3 ов і трикутників, доповнює досить незвичний меандр у нижній частині тулова - меандр ніби переривається, через кожен другий виток йдуть чотири трикутники, розташовані таким чином, що утворюють квадрат. До цього ж типу відноситься наступний фрагмент канфару («sessile kantharos») (рис. 2,6), знайдений у передмісті Ольвії36 відноситься до так званих «сидячих канфарів» і датується у межах 450-425 р. до н.е. Орнаментування має цілком класичне - два жолобки у центральній частині тулубу, під ними - ряд пальметок, досить чітко окреслених, над ними - ови. Останні розташовані майже паралельно одна до одної, прокреслена лінія та під нею - ряд пальметок, розташованих ніби під кутом. Проте, в даному екземплярі дійсно вражає якість виконання пальметок - 9 чітких пелюсток, серцевина та дві чітко окреслені волюти. До цього ж типу належать наступні фрагменти, де збереглися лише зображення ов різного розміру та якості (рис. $2,10,8)$.

Отже, чорнолакові посудини аттичного виробництва з Ольвійської колекції різних років репрезентують всі зміни у морфології й орнаментації, що характерні для відомих на сьогодні матеріалів з Афін, що доводить тісні та системні торгівельні зв'язки Ольвійського полісу з Афінами та їі округою у класичний період. Проте, слід ще раз наголосити, що все ж існують певні відмінності у штампах, оскільки більшість зображень були дійсно унікальними - майстер підходив до підбору малюнків дуже ретельно й хоча чорнолакова кераміка вважається масовою категорією посуду, стовідсоткові аналогії - рідкість. Знахідки навіть дрібних фрагментів подібних посу-

\footnotetext{
${ }^{34}$ Kunze-Götte E., Tancke K., Vierneisel K. Op. cit. P. 93.

35 Гайдукевич В.Ф. Некрополи некоторых Боспорских городов // Материалы и исследования по археологии СССР. 1959. № 69. С. 165.

36 Буйских А.В., Форнасье Й., Кузьмищев А.Г. Предместье Ольвии в свете новых украинскогерманских исследований // Записки Института истории материальной культуры РАН. 2016. № 14. С. 46-57.
} 
дин, які і є характерними для культурних нашарувань і закритих комплексів Ольвії, допомагають суттєво коригувати детальну хронологію будівельної діяльності на пам'ятці й побіжно - датувати інші категорії столового та кухонного посуду, що не мають таких надійних хронологічних маркерів.

\section{REFERENCES}

Buiskikh, A.V., Fornase, Y. \& Kuzmishchev, A.H. (2016). Predmeste Olvii v svete novykh ukrainskohermanskikh issledovanii [Olbian Suburb in the Light of New Ukrainian-German Studies]. Zapiski Instituta istorii materalnoi kultury RAN, 14, 46-57 [in Russian].

Chechulina, I.O. (2016). Shtampovanyi ornament na attychnii chornolakovii keramitsi z Olvii [Stamped Ornament From the Attic Black-Glazed Pottery from Olbio]. Arkheolohia, 2, 29-38 [in Ukrainian].

Corbett, P. (1955). Palmette Stamp from an Attik B. Glaz Workshop. Hesperia, 24, 172-186 [in Russian].

Braunova, D., Cadic, J. \& Dufkova, M. (2000). Corpus Vasorum Antiquorum. République Tchéque. Pilsen, Musée de la Boheme de l'Ouest. Pilsen; Prague: Západočeské muzeum v Plzni [in French].

Egorova, T.E. (2009). Chernolakovaia keramika IV-II vv. do n.e. s pamiatnikov Severo-Zapadnoho Kryma [Black-glazed Pottery IV-II Centuries BC from the North-Western Crimea]. Moskva [in Russian].

Egorova, T.E. (2009). Chernolakovaia keramika V-IV vv. do n.e. s procherchennym i shtampovannym ornamentom iz raskopok Pantikapeia. [Black-glazed Pottery V-IV Centuries BC With Stamped Ornament from the Excavation of Pantikapaion]. In S Mitridata duet veter. Bospor i Prichernomore $v$ antichnosti. K 70-letiiu V.P. Tolstikova (pp. 63-68). Moskva [in Russian].

Egorova, T.E. (2014). Predvaritelnyi analiz kompleksa chernolakovoi keramiki VI-II vv. do n.e. iz raskopok Pantikapeia. 1945-1992 gg. [Preliminary Analysis of the Complex of Black and White Ceramics from the $6^{\text {th }}-2^{\text {nd }}$ centuries BC from the Excavations of Panticapaeum. 1945-1992]. Drevnosti Bospora, 18, 174-195 [in Russian].

Gaidukevich, V.F. (1959). Nekropoli nekotorykh Bosporskikh horodov [Necropolis of Some Bosporus Cities]. Materialy i issledovaniia po arkheologii SSSR, 69, 154-238 [in Russian].

Gill, David W.J. (1990). Stamped Palmettes and an Attic Black-Glazed Oinochoe. Oxford Journal of Archaeology, 9 (3), 369-372. doi: 10.1111/j.1468-0092.1990.tb00378.x [in English].

Handberg, S. \& Peterson, J.H. (2010). Black-glossed pottery. In The Lower City of Olbia (Sector NGS) in the $6^{\text {th }}$ Century BC to the $4^{\text {th }}$ Century A.D. (pp. 187-196). Aarchus: Aarhus University Press [in English].

Knige, U. (1976). Kerameikos. Ergebnisse der Ausgrabungen. Band IX, Der Südhügel. Berlin [in German].

Kunze-Götte, E., Tancke, K. \& Vierneisel, K. (1999). Die Nekropole von der Mitte des 6. bis zum Ende des 5. Jahrhunderts: die Beigaben, Kerameikos. Ergebnisse der Ausgrabungen VII.2. München [in German].

Rogov, E.Ya., Kashaev, S.V. \& Fornazir, Y. (2005). Keramicheskii kompleks iz khoziaistvennykh yam poselenii Vyshesteblievskaia-11 na yuhe Tamanskoho poluostrova [Ceramic Complex From the Economic Pits of the Vyshesteblievskaia-11 Settlements in the South of the Taman Peninsula]. Bosporsie Issledovaniia, 8, 218-238 [in Russian].

Rusiaeva, A.S. \& Nazarchuk, V.Y. (2006). Atticheskaia keramika [Attic Pottery]. In Drevneishyi temenos Olvii Pontiiskoi. Materialy po arkheolohii, istorii i etnohrafii Tavrii, Supplementum, 2 (pp. 169-177). Simferopol [in Russian].

Sparkes, B.A. \& Talcott, L. (1970). Black and Plain Pottery of the 6th, 5th and 4th Centuries B.C. Series: The Athenian Agora, Vol. 12, Part 1. Princeton: American School of Classical Studies at Athens [in English].

Talcott, L. (1935). Attic Black-Glazed Stamped Ware and Other Pottery from a Fifth Century Well. Hesperia: The Journal of the American School of Classical Studies at Athens, 4 (3): The American Excavations in the Athenian Agora: Seventh Report, 476-523. doi: 10.2307/146463 [in English].

\section{Iryna Chechulina}

(Institute of Archaeology of the National Academy of Science of Ukraine, Kyiv, Ukraine)

ORCID: https://orcid.org/0000-0003-3783-6277

\section{The External Stamped Ornament on the Attic Black-Glazed Pottery from Olbia}

Stamped and incised ornaments belong to the most common methods of ornamentation of black-glazed pottery. These ornamentation methods were used from the middle of the $5^{\text {th }}$ cen- 
tury BC until the Hellenistic period, the technique spread from Athens to Italy. Pottery could be decorated by stamps both inside and outside.

The technique of covering with ornaments is quite simple - a limited set of tools was used - a cutter, a ruler, compasses and a stamp with a relief ornament on it. The ornament was made with special stamps on the surface of not yet dried up clay.

The craftsman did the stamps not simultaneously, but gradually pressing, according to the turning of the vessel in a circle, after that the pottery was fired and covered with black lacquer.

External stamps are less common than internal ones. Perhaps this is because of the fact that it is difficult to apply a stamp on the outside, taking into account the thin walls of the pottery.

Talking about external stamps it is possible to follow some trends: using a much smaller number of combinations; absence of plant ornaments, incisions; using of unique elements «diamonds», unusual meanders. The most common elements were ovules and palmettes.

The ornaments fill the central part of the body of the pottery, sometimes completely covering the free space.

Typical for external stamps is the mirroring of elements, the use of lines separating the space into several zones.

Analysis of the black-glazed pottery from Olbia has shown that only a few percent of stamped pottery had external stamps. However, the material represents all the changes in morphology and ornamentation that are typical of classical items. This again proves the close and systematic trading links of Olbia polis with Athens and its outskirts during the classical period. Nevertheless, it should be emphasized once again that there were certain differences in the stamps since most of the images were really unique - a craftsman selected drawings very carefully and although the black-glazed pottery is considered being a mass category of ware, a hundred-per-cent analogy is a rarity.

Keywords: North Black Sea region, Olbia, attic black-glazed pottery, production technique, black lacquer, stamped ornament 